\title{
Costing and Financial Management: The Financial Impact of Investment of Technology in Motors Manufacturers (T) LTD
}

\author{
Fatema Rehman \\ MBA General, Texila American University \\ E-mail:fatema.rehman@yahoo.com
}

\begin{abstract}
This study examined the relative effects of investing in technology and its financial impact on the company. The analysis was based on primary data collected from the auditor of Motor Manufacturers (T) LTD which included the cash flow statement and income statements for the years 2015 to 2017. The review also included secondary data from previous researches in order to support the results and findings obtained. The findings of study show that companies investing in technology would bring a positive financial impact for the company. The results indicate that the company can bring higher returns and better liquidity through new technology however needs to maintain it throughout the years in order to bring constant improvement. In order to analyze the impact of investment in technology, the financial analysis would include the ratio analysis, budgeting, benchmarking, risk management and investment appraisal. The constantly changing environment increases the need of investing in technology however the negative financial impact becomes a concern for a company's management. This therefore causes the management in neglecting the idea of investing in technology which does not bring any positive impact that it could have brought to the company if the management would have forecasted its' financial and investment appraisal.
\end{abstract}

Keywords: Finance, Impact, Investment, Technology.

\section{Introduction}

Companies operate in an environment that keeps on changing from time to time which affects the company in one way or the other. In order to remain competitive and survive in the market, the company needs to bring about changes in its decisions and strategies. Sometimes the company can be required to invest in new technology in order to meet the standards of the market place.

Companies invest in technology to enable their employees to increase productivity as they are able to reduce time spent and increase their output simultaneously (Dewan and Kraemer 2000). The cost of investing in technology needs to be outbalanced by the benefits and profit of investing in the long-terms in order to prove to be beneficial to the company.

Investment in technology could bring about some benefits but could also bring negative effects if not implemented correctly. This research will therefore look at the benefits and disadvantages as well as the overall outcome of investing in technology in a local established company.

Motor Manufacturers is a medium-scale industry based in Tabora. The firm manufactures and designs agro-construction equipment and tools such as hullers, oxen carts, brick-lying machines and much more. The firm started its operations in 2012 with revenue of 5,976,875 only and faced losses in the first two years of operations.

The company started to do substantially well after the third year when it invested in technology with $10,000,000$ to create an innovative product of a watering machine for farmers that is operated through solar power. Currently the company has 80 employees and revenue of 29,470,769 which comes from the result of the investment in technology that met the rural farmers' needs and of the environment. The company is looking into expanding its business across different regions and reaching up to 200 employees by 2020 . 


\section{Research Questions}

1. Analyzing the financial impact of the decision of investment through financial ratios, techniques and data.

2. Evaluating the decision of investment to the company's profitability and growth.

3. Analyzing the progress of the company with its competitors' through best-in-class benchmarking.

4. Assessing the source of investment and its utilization.

5. Analyzing budgeting in relation to the decision of investment and its importance.

6. Assessing any risks associated with the decision of investment towards the company.

This review will determine the outcome of a decision for investment in technology within a company. The benefits, disadvantages, risk and impact will be discussed in this research in terms of both quantitative and qualitative appraisal.

\section{Literature Review\& Methods}

\section{Investment in Technology}

According to $\mathrm{Li}$ et al (2000), investment in technology does not directly enable the employees to increase their productivity though many researchers such as Gyampoh-Vidogah et al (1999) claims that investment in technology will improve the performance of the company in the long term. When the decision for investment in technology turns out to be successful, the company not only makes high returns from the decision but also becomes responsible for transformingtheir business as well as their industry sector (O’Brian 1999)

According to Irani et al (1999), the biggest problem in investing in technology arises when the company is unable to predict and analyze the benefits of the result. Different appraisal techniques such as the Net Present Value (NPV), payback period, Return on Investment (ROI) and Internal Rate of Return (IRR) are mostly used by companies when evaluating their decision of investment (Ballantine and Stray 1999).

\section{Quantitative Appraisal}

Evaluating the benefits of investing in technology through quantifiable terms could include using techniques such as the appraisal of investment through ROI, NPV and IRR or through the financial statement using ratios such as net profit margin, current ratio and more. The analysis of the budget is also included under this appraisal.

\section{Investment Appraisal}

The investment appraisal could be carried out using techniques such as ROI, NPV, IRR and the payback period. In order to get the exact amount of return and time spent, the NPV and IRR technique should be used however the project size is not measured which can cause conflicting or misleading answers.

The payback period is easy to use therefore is widely used despite its limitations of not effectively evaluating the project since it does not consider the returns the way it's used in other techniques (Brigham and Ehrhardt 2005).

In order to know the net gain or loss from the project companies should use ROI which helps to identify the project's outcome and detailed financial analysis (Botchkarev and Andru2011). Another option is NPV that is used to analyze the profitability of the decision where the decision/project with highest NPV is to be chosen (Brigham and Ehrhardt 2005).

\section{Financial Ratios Appraisal}

The financial data used to analyze the ratios includes the comprehensive statement (profit/loss statement), balance sheet and the cash flow statements which are not independent but are linked to the same system of finance in a company (Walsh 2003).

Financial data from the company are obtained in order to calculate the ratios and then analyze through comparison between different years. According to Pandey (2005), ratios are the relation of two or more mathematical outcomes and identified these ratios to be liquidity, leverage, activity and profitability.

\section{Budgeting}

According to Musaazi (1982), budget is the financial strategy where the objectives are put in place according to that financial strategy to turn it into reality. The allotment of financial resources to a company's activities, divisions and investment is known as the process of budgeting (Blumentritt 2006).

Flexible budgeting is preferred to be used since it allows adapting according to the environment as opposed to traditional budgeting 
which gives a rigid budget that employees have to maintain despite the changes in the environment. Budget is seen to be as a management control in the organizations' systems as stated by Otley (1978). Many researchers such as Abdel-Kader and Luther (2006) and Uyar (2009) have demonstrated to prove that budgeting is used as a control mechanism as well as a planning tool for an organization.

\section{Qualitative Appraisal}

Evaluating the investment in technology in terms of qualitative terms could include conducting the SWOT analysis of the company to understand the risks or opportunities to the company. The risk management, source of investment and benchmarking has also been carried out to evaluate the decision.

\section{Risks on Investment}

According to Lawrence (1976) risk can be defined as the measure of possibility of undesirable consequences arising. Risks are supposed to be communicated, consulted, analyzed and monitored once they are identified in order to ensure the risks do not adversely affect in the future (Risk Management ISO 2009).

\section{Benchmarking}

Benchmarking has been defined as the process of comparing one's performance with a competitor with the purpose of improving through adaption of best practice approach (Edith Cowan University 2011). According to Epper (1999), benchmarking could be successful for a company after it has done a self-analysis first in order to understand its own processes more clearly before it tries to understand its competitors. A company needs to be aware of the likely problems that could arise resulting the shortfall in results from its competitors and should be able to come up with a solution through agreed decisions and plans (Wilson et al 2000). Not only can the company compare itself with its competitor but also with the best in the industry; best in previous years or best in the market as stated by Johnson, Scholes and Whittington (2008).

\section{Source of Investment}

The source of investment depends on the project being invested in where the source can either be internal or external. Internal funding is mostly preferred to avoid the monitoring and checking resulting from external funding (Brealey et al 2001). Where the investment is huge or for expansion of operations then external funding is looked into. External funding is usually used when there is limited cash flow from the company's operations (Watson and Head 2007). Another option is the equity financing which is not preferred when compared to debt financing (Eckbo 2008).

\section{Research Gap}

Previous researchers such as Khan (2007) and Venkatesh et al (2010) have analyzed the benefits and challenges of investing in technology in many companies, however this research will be conducted on Motor Manufacturers and its investment in technology which has never been evaluated by previous researchers. The benefits, challenges and overall outcome will be analyzed in both quantitative and qualitative terms in order to determine the success or failure of investment in technology at the bank.

\section{Data Collection}

This review has used secondary method to obtain the information relating to the topic. The quantitative and qualitative methods were used where financial data and the evaluation of the strategic decision was carried out through the use of SWOT analysis.

\section{Data Management}

The data collected was ensured to be reliable since it was collected from sources that were considered reliable and authentic. The information and financial statements for Motor Manufacturers was derived from the company's management through emails and from auditor, Mr. Denis Demarco who was on a visit to Dares-Salaam through personal meetings. Therefore, all data derived is considered as valid and reliable.

\section{Findings and Analysis}

\section{Financial Analysis}

The analysis of the calculation of the ratios (Appendix 1) is as follows:

\section{ROCE}


The calculation shows an increase in ROCE after the year of investment from 1.9\% in 2015 to $4.2 \%$ in 2016 . This shows a good return on the capital employed following the investment in technology and a substantial increase in the profit before tax. However, the ROCE decreased in 2017 due to a slight decrease in profit before tax along with an increase in the capital employed. The decrease was not lower than the ROCE of 2015 where it was calculated to be $2.8 \%$ which still shows the result of an increase from the investment of technology.

\section{Current Ratio}

Motor Manufacturers' current ratio had an increase from 1.9 in 2015 to 3.0 in 2017. This shows that the company has been able to increase its current assets and the investment has not affected its liquidity. However, the increase needs to be managed where the current assets should be used efficiently and working capital could be used for other investments.

\section{Profit Margin}

There was an increase in profit margin from $19.6 \%$ in 2015 to $25 \%$ in 2016 which shows the investment in machinery has been able to improve the company's profitability and its margin over time. The profit margin however slightly decreased to $24.7 \%$ due to a decrease in profit before tax and revenue in that year (2017).

\section{Debt Ratio}

Despite the acquiring of debt for the investment in technology the debt ratio was maintained where it was 0.54 in 2015 and 2016 while it slightly reduced to 0.52 in 2017 . This shows that the company was able to slightly reduce its financial risk and the investment did not adversely affect the company through acquiring a debt.

\section{Best-in-class Benchmarking}

Simba Manufacturer is a competitor as well as the best-in-class for the agriculture industry in terms of the local firms. Motor Manufacturers and Simba Manufacturer were analyzed for the year 2017 with financial ratios (Appendix 4).

The analysis shows that Simba Manufacturer has better profitability in terms of the profit margin and ROCE. Simba Manufacturer has a higher profit as well as revenue which show that Motor Manufacturer is yet to achieve that target in order to be the best in the industry. However, in terms of liquidity Motor Manufacturers holds a better position than Simba Manufacturer where they are more prone to financial risk and are less likely able to get into more debts for future investments.

Motor Manufacturers despite the lower profitability than Simba Manufacturer has a better liquidity position and is able to invest through obtaining debt and therefore expand in the market with new projects.

\section{Budgeting}

The company has done substantially well in terms of maintaining low variance between forecasted and actual figures (Appendix 6). Motor Manufacturers used traditional budgeting method where figures were set before the start of the financial year and were not to be changed despite any change in the environment or market place. This could cause biased analysis where the budget was not altered according to the situation especially in a country where inflation is always on the rise. The variance however was not too high therefore showing that the company was able to mostly achieve the forecasted figures.

In terms of the investment, the forecasted figures were achieved with a positive variance for the revenue with $12 \%$ higher than forecasted figure. The expenses were lesser than forecasted by $-15 \%$ and therefore brought down the variance for profit to $-2 \%$ only. The forecasted figures in 2017 was not achieved the way it was in 2016 probably because of the overachievement in 2016 caused the company to set the budget for 2017 with higher figures than expected. 2017 in Tanzania was a year with inflation and tight economy therefore the figures were not easily achieved though expenses were less than predicted $(5 \%)$.

\section{Risk Management}

Motor Manufacturers knew the risk of investing in a new technology for a product carries more risk especially since it was after two years of being founded. The company had the risk of acquiring loan as well as using $20 \%$ of its own equity for the investment. This finance risk was however mitigated as the company benefitted from the investment in the next year with increasing revenue and profit.

The company had mitigated and solved the 
risk of not keeping with the market needs by investing in the technology and offering a new product that was introduced according to the advanced technology and convenience need in the market. The company also dealt with the risk of losing customers by introducing the new product through investment of technology which was not only convenient but also cost-effective.

The inflation risk as well as risk from change of policies from the government as stated in the SWOT analysis (Appendix5) shows that the company has to consider the economy of Tanzania and government decisions in order to make sure the operations are not negatively affected. Due the rise in costs in Tanzania, Motor Manufacturers obtained a minimum loan amount instead of a huge amount as it knew it would not be able to suffice with the profitability it achieves. This enabled Motor Manufacturers to reduce the negative risk of inflation by investing a small amount that would be recovered soon as well as avoid negative impact arising from changing government policies.

\section{Investment Appraisal}

The investment appraisal carried out for this project was analyzed through two common techniques; NPV and Payback Period (Appendix $2 \& 3)$.

The actual NPV was calculated to be lower than the forecasted NPV however the actual NPV turned to be positive which shows that the revenue from the project is higher than the costs. The actual Payback Period shows that the investment amount has been recovered within 23 months which is sooner than the forecasted payback period of 29 months.

This therefore shows that despite not being able to achieve the forecasted NPV it has been able to still obtain a positive amount as well as recover the investment amount within a shorter period of time. The analysis could be more detailed by using other techniques such as IRR however, due to lack of time and resources the analysis for the investment was carried out through NPV and Payback Period only.

\section{Source of Finance}

Motor Manufacturers obtained a loan for $80 \%$ of its investment while $20 \%$ was obtained from the company's equity.

This enabled the company to not place its risk of investment on one option only and could recover easily.

The company was able to recover the investment from its shareholders where the ROCE (Appendix 1) increased and the amount invested was recovered. The debt amount can be easily be recovered through the company's cash or assets since the current ratio (Appendix 1) is high and the invested amount has been recovered as shown in the Payback Period (Appendix 3).

\section{Conclusion and Recommendation}

\section{Conclusion}

Motor Manufacturers' investment in technology was successful as seen in the quantitative and qualitative analysis carried out in this review. The company was able to recover its investment in a shorter period of time and achieve higher profitability from the time it invested in the technology. The investment appraisal therefore was positive for the company and the financial data was analyzed with the outcome of favorable terms.

The company was able to manage its risks and invested with precaution through a small amount and dividing the source of income to equity and debt to mitigate the risk of financing. Motor Manufacturers were able to achieve some of its forecasted figures as well as reducing the variance which shows it was able to achieve a better position than before.

The company was not only able to increase its profitability, but also increased its customers of rural farmers since the new technology offered a cost-efficient machinery and convenient usage. The company was also able to expand its product base through the new technology and therefore increase its market share and also enabled the company to look into more projects for investment after experiencing the benefits for this particular investment of technology.

Motor Manufacturers however faced slightly lower profitability, ROCE and revenue in 2017 which could be due to external factors such as the tight economy and high inflation rates. The company also needs to improve itself to compete better with its competitors as seen in the benchmarking analysis where Simba Manufacturer is potentially better in profit and performance except for liquidity. 


\section{Limitation}

This review was limited due to time and resources where the author could not meet the management in person for company details but had to use email for communication. The author also faced the restriction of not getting information of the company from sources such as the websites or published annual reports since it is a locally established medium scale company. Local companies in Tanzania are hesitant in providing financial data of the company due to which personally meeting the auditor and obtaining information was not through reference sources but through authors' personal interaction with auditor.

\section{Recommendations}

In relation to the findings and conclusion, Motor Manufacturers needs to find ways of growing its profitability and revenue since it had faced a slight decrease in 2017. Since the investment in the technology proved to be successful in terms of higher ROCE, revenue, profit and overall performance in 2016, the company should invest in latest technology to meet the changing needs of the market. The

Appendix 1 company's liquidity is in good position where company has more current assets compared to its liabilities and previous investment has already been recovered, the company can therefore look into financing a new investment.

Moreover, Motor Manufacturers needs to adapt to flexible budgeting in order to avoid high variance due to change in environment or government rules which the company cannot control. This could be seen in 2017 where the inflation was high in Tanzania therefore the variance was high and forecasted figures were not achieved in contrast to 2016. The company needs to continue assessing its risks in order to successfully operate in the industry which it did well when assessing risks of the investment in terms of source of finance.

\section{Self-Evaluation}

This research has enabled the author to learn about the local company's financial stability as well as decisions of investment in terms of small yet largely impacting projects. The author learnt how to analyze financial data in relation to a certain decision as well as concluding the impact of that decision to the company.

\section{Ratio Analysis}

\begin{tabular}{|c|c|c|c|}
\hline Ratios & 2015 & 2016 & 2017 \\
\hline ROCE & $5,256,832$ & $16,916,851$ & $14,688,002$ \\
\hline Net profit before Interest and Tax & $\overline{278,004,501} \times 100$ & $\overline{403,332,698} \times 100$ & $\overline{533,030,809} \times 100$ \\
\hline Capital employed & $=1.9 \%$ & $=4.2 \%$ & $=2.8 \%$ \\
\hline Current Ratio & $233,346,282=19$ & $358,009,919$ & $481,762,370$ \\
\hline Current Assets & $\overline{117,800,358}=1.9$ & $\overline{168,009,938}=2.1$ & $\overline{160,159,099}=$ \\
\hline$\overline{\text { Current Liabilities }}$ & & & \\
\hline Profit Margin & $5,256,832$ & $16,916,851$ & $14,688,002$ \\
\hline Profit before interest tax & 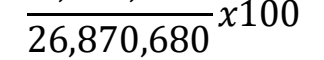 & $\frac{67,428,891}{6700}$ & $\overline{59,470,769} \times 100$ \\
\hline Revenue & $=19.6 \%$ & $=25 \%$ & $=24.7 \%$ \\
\hline Debt Ratio & $150,000,000$ & $218,659,170$ & $276,256,321$ \\
\hline Total Liabilites & $\overline{278,004,501}$ & $\overline{403,332,698}$ & $\overline{533,230,809}$ \\
\hline Total Assets & $=0.54$ & $=0.54$ & $=0.52$ \\
\hline
\end{tabular}

Appendix 2

\section{Forecasted NPV}

\begin{tabular}{|l|l|l|l|}
\hline Year & Cash Flow & Discount Rate (8\% ) & Present Value \\
\hline Investment (2015) & $10,000,000$ & 1.00 & $(10,000,000)$ \\
\hline 2015 & $2,500,000$ & $(1+0.08)^{\wedge} 1$ & $2,314,815$ \\
\hline 2016 & $4,890,800$ & $(1+0.08)^{\wedge} 2$ & $4,193,073$ \\
\hline 2017 & $6,980,770$ & $(1+0.08)^{\wedge} 3$ & $5,541,560$ \\
\hline NPV & & & $2,049,448$ \\
\hline
\end{tabular}




\section{Actual NPV}

\begin{tabular}{|l|l|l|l|}
\hline Books & Books & Books & Books \\
\hline Investment (2015) & $10,000,000$ & 1.00 & $(10,000,000)$ \\
\hline 2015 & $5,927,762$ & $(1+0.08)^{\wedge} 1$ & $5,488,669$ \\
\hline 2016 & $4,564,448$ & $(1+0.08)^{\wedge} 2$ & $3,913,279$ \\
\hline 2017 & $2,096,120$ & $(1+0.08)^{\wedge} 3$ & $1,663,968$ \\
\hline NPV & & & $1,065,916$ \\
\hline
\end{tabular}

\section{Appendix 3}

\section{Forecasted Payback Period}

\begin{tabular}{|l|l|l|}
\hline Books & Books & Books \\
\hline Investment (2015) & $10,000,000$ & $-10,000,000$ \\
\hline 2015 & $2,500,000$ & $-7,500,000$ \\
\hline 2016 & $4,890,800$ & $-2,609,200$ \\
\hline 2017 & $6,980,770$ & $4,371,570$ \\
\hline \multicolumn{2}{|l|}{ Payback Period: 29 Months } \\
\hline
\end{tabular}

\section{Actual Payback Period}

\begin{tabular}{|l|l|l|}
\hline Year & Cash Flow & Cumulative Cash Flow \\
\hline Investment (2015) & $10,000,000$ & $-10,000,000$ \\
\hline 2015 & $5,927,762$ & $-4,072,238$ \\
\hline 2016 & $4,564,448$ & 492,210 \\
\hline 2017 & $2,096,120$ & $2,588,330$ \\
\hline \multicolumn{2}{|l}{ Payback Period: 23 Months } \\
\hline
\end{tabular}

\section{Appendix 4}

Competitor Analysis for the year 2017

\begin{tabular}{|l|l|l|}
\hline Ratios & Motor Manufacturers & Simba Manufacturer \\
\hline ROCE & $2.8 \%$ & $14.7 \%$ \\
\hline Current Ratio & 3.0 & 0.85 \\
\hline Profit Margin & $24.7 \%$ & $43.4 \%$ \\
\hline Debt Ratio & 0.52 & 0.82 \\
\hline
\end{tabular}

\section{Appendix 5}

\section{SWOT Analysis}

\begin{tabular}{|l|l|}
\hline Strengths & $\begin{array}{l}\text { 1. The company is able to provide end-to-end suitable farming tools to both medium and } \\
\text { large-scale farmers. } \\
\text { 2. The tools provided by the company are quality designed and appropriate for the } \\
\text { environment of the country. } \\
\text { 3. The company has a research and development unit that comes up with innovative [projects } \\
\text { to undertake for its profitability. }\end{array}$ \\
\hline Weaknesses & $\begin{array}{l}\text { 1. The company has limited capital to execute its projects } \\
\text { 2. The company faces lack of government support in terms of material and technological } \\
\text { support which would have otherwise created investment more accessible. }\end{array}$ \\
\hline Opportunity & $\begin{array}{l}\text { 1. The agriculture industry in Tanzania is continuously growing therefore providing wider } \\
\text { adaptability of farmers to the machines that the company produces. }\end{array}$ \\
\hline
\end{tabular}




\begin{tabular}{|l|l|}
\hline Threat & $\begin{array}{l}\text { 2. Agriculture is the backbone of the economy of Tanzania that makes investment more } \\
\text { volatile }\end{array}$ \\
$\begin{array}{l}\text { 1. Government restriction and change in policies affects the company's decisions and } \\
\text { operations. } \\
\text { 2. Inflation status in Tanzania causes the company to make decisions with precaution in order } \\
\text { to avoid negative impacts. }\end{array}$ \\
\hline
\end{tabular}

\section{Appendix 6}

\section{Budgeting}

\begin{tabular}{|l|l|l|l|}
\hline \multirow{2}{*}{ Details } & Jun-2017 & Jun-2017 & \multirow{2}{*}{ Variance } \\
\cline { 2 - 3 } & Actual & Budget & \\
\hline Revenue & $59,470,769$ & $87,972,000$ & $(28,501,231)-3 \%$ \\
\hline Short term rentals & $1,611,360$ & 312,000 & $1,299,360$ \\
\hline Long term rentals & $6,642,657$ & $27,660,000$ & $(21,017,343)$ \\
\hline Hire Purchase/outright sales & $21,216,752$ & $60,000,000$ & $(38,783,248)$ \\
\hline Cost of Sales & - & $25,550,000$ & $(25,550,000)$ \\
\hline Cost of Sales & - & $25,550,000$ & $(25,550,000)$ \\
\hline Gross Profit & $59,470,769$ & $62,422,000$ & $(32,951,231)$ \\
\hline Other income & - & - & - \\
\hline Other Income & & - & - \\
\hline Operating expenses & $44,138,771$ & $38,552,179$ & $42,823,6205 \%$ \\
\hline Other expenses & 386,500 & 232,755 & 153,745 \\
\hline Advertising \& promotion & - & 838,719 & $(838,719)$ \\
\hline Audit \& consulting fees & - & 676,875 & $(676,875)$ \\
\hline Bank charges & 664,406 & 373,139 & 291,267 \\
\hline Client set ups & - & 31,500 & $(31,500)$ \\
\hline Electricity and water & $1,417,364$ & $1,611,256$ & $(193,892)$ \\
\hline Courier \& postage & - & 8,750 & $(8,750)$ \\
\hline Depreciation & $2,323,969$ & $2,535,637$ & $(211,668)$ \\
\hline Legal fees & - & 30,476 & $(30,476)$ \\
\hline Insurance & $11,034,605$ & $1,236,261$ & $9,798,343$ \\
\hline Levies & - & 113,750 & $(113,750)$ \\
\hline Motor vehicle - petrol \& oil & $1,450,000$ & $2,235,625$ & $(785,625)$ \\
\hline $\begin{array}{l}\text { Motor vehicle - repairs \& } \\
\text { maintenance }\end{array}$ & $4,604,300$ & $3,504,371$ & $1,099,929$ \\
\hline $\begin{array}{l}\text { Motor vehicle - insurance \& } \\
\text { license }\end{array}$ & - & 120,750 & $(120,750)$ \\
\hline Printing \& stationery & & 254,415 & $(254,415)$ \\
\hline Salaries \& wages employees & $22,257,900$ & $24,747,900$ & $(2,490,000)$ \\
\hline Profit Before Tax & $(15,332,058)$ & $23,869,821$ & $(1,611,921)-7 \%$ \\
\hline
\end{tabular}

Source: Motors Manufacturers Management

\section{Acknowledgement}

All thanks to The Almighty for giving me the ability of completing this review.

I would like to give special thanks to my friends and family who have provided me with continuous support throughout this review.
Special thanks to the Management of Motor Manufacturers (T) LTD and Auditor, Mr. Denis Demarco for providing information and financial data that was used for this review. 


\section{Reference}

[1] Walsh, C. (2003) Key Management Ratios (Third Edition) Harlow, UK: Pearson Education. Arnold, G. (2005) Handbook of Corporate Finance, Harlow, UK: Pearson Education.

[2] http://www.ieng-group.com/

[3] http://www.globdev.org/files/ProceedingsThird\%20Annual\%20SIG\%20Globdev\%20Worksho p/24-PAPER-Dedrick-Kraemer-Shih-IT-and-

Productivity.pdf

[4] http://www.vvenkatesh.com/wp-

content/uploads/2015/11/Venkateshetal_POM_2010. pdf

[5] http://faculty.usfsp.edu/gkearns/Articles2/benchm arking\%20IT\%20benefits.pdf

[6] http://www.hrmars.com/admin/pics/1576.pdf

[7] https://www.ncbi.nlm.nih.gov/pmc/articles/PMC4 084908/

[8] http://www.candor-holdings.com/equities/wpcontent/uploads/sites/2/2016/02/types_of_financial_r atios_19mar_2012.pdf
[9] https://www.coursehero.com/file/p1qis61/27-

Definition-of-Ratio-Ratios-has-been-defined-by-

different-authors-in-many/

[10] https://www.linkedin.com/pulse/budgetingeducational-management-basil-ezeugo

[11] http://conferinta2013.academiacomerciala.ro/_V

OLCONF2013PDF/volumconferinta/PURPOSE\%20

FOR\%20BUDGETING\%20-

\%20LITERATURE\%20REVIEW_pintea.pdf

[12] http://www.iiakm.org/ojakm/articles/2015/volum e3_3/OJAKM_Volume3_3pp17-26.pdf

[13] https://intranet.ecu.edu.au/data/assets/pdf_file/00 10/357193/Benchmarking-Literature-Review.pdf [14] http://www.proz-

x.com/stephanlangdon/Library/CESACORE/Prentice $\% 20 \mathrm{Hall} \% 20$ Exploring\%20Corporate $\% 20$ Strategy $\%$ 208th.pdf

[15] http://www.cek.ef.uni-lj.si/magister/torteska976B.pdf

[16] https://esa.un.org/techcoop/documents/pn_invest menttechnologypolicynote.pdf 